\title{
Prevalence of violence against the elderly and associated factors - a population based study in Florianópolis, Santa Catarina
}

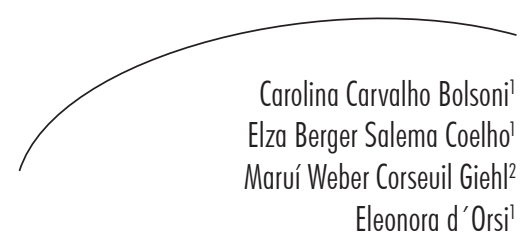

Abstract

Objective: To estimate the prevalence of violence among the elderly and to analyze its association with demographic, socioeconomic and health conditions. Method: A cross sectional population-based study was conducted of 1,705 individuals aged 60 years or older living in the city of Florianópolis in the state of Santa Catarina, between 2009 to 2010. Verbal, psychological, physical and financial violence was evaluated with a questionnaire used in the Pesquisa Saúde Bem-estar e Envelhecimento (Health and Wellbeing in Aging Survey) (SABE). Prevalence was calculated for each type of violence and the overall prevalence of violence was identified using the categories of the explanatory variables. Logistic regression was used to identify the factors associated with violence. Results: The general prevalence of violence was approximately $13.0 \%$, while verbal violence occurred among $11.0 \%$ of respondents. The adjusted analysis showed that being female $(\mathrm{OR}=2.08)$ and elderly persons who were single or divorced were $66 \%$ more likely to suffer violence. Those who lived with their children or grandchildren were twice as likely to suffer violence (95\% CI: 1:40 to 3:40). Conclusions: Although the results showed that the prevalence of violence against the elderly was greater than predicted by the WHO, we suspect that this number may be even higher. Due to the complexity of the theme, it is possible that elderly persons are afraid to reveal that they are victims of violence, as in most cases, the aggressors are family members.

\footnotetext{
Universidade Federal de Santa Catarina, Centro de Ciências da Saúde, Programa de Pós-Graduação em Saúde Coletiva. Florianópolis, SC, Brasil

2 Universidade Federal de Santa Catarina, Centro de Ciências da Saúde, Programa de Pós-Graduação em Nutrição. Florianópolis, SC, Brasil

Correspondence

Carolina Carvalho Bolsoni

Email: carolziinha.flor@gmail.com
}

Keywords: elderly; violence; domestic violence; abuse of the elderly; violence against the elderly; cross-sectional studies. 


\section{INTRODUCTION}

Population aging is a global phenomenon. The fastest growing section of the Brazilian population is the elderly. ${ }^{1}$ A number of strategies are required to ensure the dignity of these elderly individuals, including: the promotion of healthy and active aging; consideration during the creation and execution of specific public policies and acts such as the Política Nacional de Saúde da Pessoa Idosa (National Health Policy for the Elderly) and the Estatuto do Idoso (the Statute of the Elderly); ;,3 and the denouncing and prevention of violence against the elderly.

Violence against the elderly is defined as an act of aggression or an omission that may be intentional or involuntary. This abuse can be psychological or physical in nature and may involve financial or material mistreatment. ${ }^{4}$

A study conducted in Spain demonstrated reported the following types of violence: emotional (4.6\%); physical (1.6\%); sexual ( $0.6 \%)$; and financial $(5.6 \%){ }^{5}$ In Nigeria, $30 \%$ of the elderly participants in a study claimed to have suffered from some form of violence. ${ }^{6}$

In Brazil, a study conducted in the city of Niterói investigated the prevalence of violence against individuals aged 60 years or more, confirming that $43 \%$ of this aggression was psychological and $9.6 \%$ was physical. ${ }^{7}$ Other studies have shown that elderly individuals who are subjected to violence are generally single women of an advanced age with a low level of education and some form of physical or psychological dependence which has led to them living with either their children, grandchildren or daughters-in-law. ${ }^{8,9}$

In western culture, violence against the elderly occurs irrespective of socioeconomic level and is linked to the socially-accepted idea that the elderly are unproductive and cannot learn. ${ }^{10,11}$ It is believed that this violence damages the functional capacity of the elderly and any type of abuse causes unnecessary suffering, injury, pain and loss, while violating the human rights of individuals and reducing their quality of life. ${ }^{4,12}$
Violence against the elderly is often hidden. One form of investigating this phenomenon is to conduct research in order to publicize the issue and adopt measures to prevent it. ${ }^{10}$ Therefore, the aim of the present study was to estimate the prevalence of violence against the elderly and to analyze correlations with demographic, socioeconomic and health factors in a capital city in the south of Brazil.

\section{METHOD}

\section{Study design and population}

This home-based cross-sectional population study addressed all individuals aged 60 years or more in the city of Florianópolis, in the state of Santa Catarina. This research is part of the inquest into the health conditions of the elderly known as EpiFloripa Idoso (2009-2010), which was financed by the Conselho Nacional de Desenvolvimento Cientifico e Tecnológico (the National Council for Scientific Development and Technology) (CNPq).

In 2010, the population of Florianópolis, capital of the state of Santa Catarina, was 421,240, of which 47,076 were aged 60 years or more $(19,786$ men and 27,289 women). Thus, the elderly represent $11.1 \%$ of the total population. At the time of this survey, the city had been awarded a human development index of 0.88, which is the third highest in Brazil. Life expectancy in the city was 72.8 years.

\section{Sampling}

The following parameters were considered when calculating the sample size: a population of 44,460; an unknown prevalence of $50 \%$; a sampling error of four percentage points; a confidence interval of 95\% and a design effect of two. In addition, 20\% was added for predicted losses and $15 \%$ for studies of association, giving a desirable sample of at least 1,599 people. Version 6.04 of Epi-Info software (public domain) was used in these calculations.

The sampling was conducted by conglomerates in two stages. Based on the data from the Instituto 
Brasileiro de Geografia e Estatística (the Brazilian Institute of Geography and Statistics) (IBGE), the 420 urban census sectors of the city were ordered by the mean monthly income of the head of the household (residing in the sector) and stratified into deciles. In the following stage, 80 sectors were systematically drawn (eight from each income decile). The domiciles were considered as second stage units. Since the record of domiciles in each sector was outdated (the last census prior to the present study was conducted in 2000), the quantity of private inhabited domiciles in each unit was counted.

The number of domiciles ranged from 61 to 725. In order to decrease the coefficient of variation for the quantity of domiciles in the sampling units, the sectors were fused and divided, respecting the corresponding income decile and geographic proximity. Thus, the initial coefficient of variation decreased from $52.7 \%$ ( $\mathrm{n}=80$ sectors) to $35.2 \%$ ( $\mathrm{n}=83$ sectors). Subsequently, the domiciles were drawn systematically and all elderly individuals residing in the domiciles selected were invited to participate in the study. Due to the financial resources available, an estimated 23 interviews were conducted per census sector, which allowed a greater variability of the sample. In total, 1911 elderly individuals were eligible for the study. The non-response rate was $10.9 \%$, which led to a final sample of 1705 elderly individuals, all of whom were effectively interviewed. Institutionalized elderly individuals were excluded from the present study.

Individuals who were travelling or not contacted after four visits from the interviewers (at least once at night and once on the weekend) were considered as losses. Those who refused to answer the questionnaire were classified as refusals.

\section{Data collection}

A standardized and pre-tested questionnaire was applied by fully-trained and educated interviewers who were available on a full-time basis for the field research. Prior to the collection, a pilot study was conducted with 99 elderly individuals in sectors that were not sampled in the present study. The interview was conducted face to face and a Personal Digital Assistant (PDA) was used to record the data.

On a weekly basis, the consistency of the data was confirmed and the quality control of the interviews was monitored by telephone, based on the application of a reduced questionnaire $(10 \%)$ from the randomly selected interviews.

Four types of violence were investigated in the present study (verbal, psychological, physical and financial) using the same questionnaire that was used in the Health, Wellbeing and Aging Survey (SABE), ${ }^{13}$ which was a longitudinal study of the living conditions of elderly individuals in the city of São Paulo (2006). This questionnaire contains questions that determine whether the elderly individual had been subjected to verbal, financial, psychological or physical violence.

The following questions were used to form the variables of domestic violence against the elderly: 1) "Have you suffered any type of violence?"; 2) "In the last year, have any of your friends or family shouted at you for no reason?"; 3) "In the last year, have any of your friends or family called you a name that you don't like??"; 4) "In the last year, have any of your friends or family touched or spent your money without your permission?"; 5) "In the last year, have any of your friends or family threatened you because you did not do what they wanted you to do?"; 6) "In the last year, have any of your friends or family bit or slapped you?"; 7) "In the last year, have any of your friends or family shaken you?", and 8) "In the lastyear, have any of your friends or family stolen your money or something else belonging to you?". Each question had three possible answers: yes; no; or ignored. The construction of the variable outcome, which was general violence, only required the participant to answer yes to one of these questions. For the present study, questions 2 and 3 were classified as verbal violence, while questions 4 and 8 were characterized as financial violence. Question 5 was considered to represent psychological violence and questions 6 and 7 were classified as physical violence.

Based on a literature review, the following exploratory variables were selected: gender; age (60 to 69 years, 70 to 79 years and 80 or more years); self-reported skin color (white, brown or black, 
with those who described themselves as yellow or Asian Brazilian ( $\mathrm{n}=12)$ or indigenous $(\mathrm{n}=16)$ excluded due to the reduced sample); education ( $\geq 12$ years of study, 9 to 11 years, 5 to 8 years, $\leq 4$ years) and per capita family income, which was stratified into quartiles (1st quartile: $\leq \mathrm{R} \$ 327.50$; 2nd quartile: between $\mathrm{R} \$ 327.50$ and $\mathrm{R} \$ 700.00$; 3rd quartile: between $\mathrm{R} \$ 700.00$ and $\mathrm{R} \$ 1,500.00$ and 4th quartile: $>\mathrm{R} \$ 1,500.00)$.

Health conditions and functional capacity were concomitantly determined by applying the basic and instrumental activities of daily living (ADL) scale. The following classifications were made: independent (no disability/difficulty with any of the activities); mild dependence (disability/ difficulty with 1-3 activities); and moderate/severe dependence (disability/difficulty with four or more activities). ${ }^{14}$ The cognitive state of the participant was determined using the Mini-Mental State Examination (MMSE) $)^{15}$ and dichotomized into "absence of cognitive deficits" and "probable cognitive deficits" using cutoff points that considered the level of education of the individual and self-perceptions of their health (very good/ good, regular or poor/very poor).

Questions were also asked to determine if the participants had a caregiver (yes or no) and who was their main caregiver (spouse/partner, child/grandchild, formal caregiver or other). The participants were also asked to specify who they lived with (spouse/other people of their own age, alone or with children/grandchildren).

\section{Data analysis}

The prevalence of each type of violence (general violence) was calculated in accordance with the categories of the exploratory variables. Subsequently, logistical regression was used to determine the factors associated with general violence. This provided the odds ratio (OR) for the bivariate and multivariate analysis, together with their respective confidence intervals (CI95\%). Based on the results from the univariate analysis, all variables that exhibited $p \leq 0.20$ were included in the multivariate analysis. Only those that exhibited $p \leq 0.05$ remained in the final model.

Modeling blocks were used to input the variables: the first block contained the demographic variables; the second contained the socioeconomic variables; the third block contained the health conditions; and the final block contained the variables related to the caregiver and who lived with the participant.

The analysis was conducted considering the effect of the sampling design (conglomerates) and incorporating the sampling weights. This analysis was conducted using Stata 11.0 software (Stata Corp., College Station, USA).

\section{Ethical aspects}

This project followed the regulations of resolution 466/2012 of the Conselho Nacional de Saúde (the National Health Council) and was approved by the Human Research Ethics Committee of the Universidade Federal de Santa Catarina (Santa Catarina Federal University) (protocol 352/2008). The interviewees signed a free and informed consent form.

\section{RESULTS}

The domiciles that were drawn contained 1911 eligible elderly individuals, of whom 1705 were effectively interviewed (response rate of $89.2 \%$ ). In total, there were 206 losses and refusals for the following reasons: "nobody was home"; "the elderly individual was away"; "an interview was scheduled but they did not show up"; "they were on holidays"; "they were very sick"; "there was a dangerous dog on the premises". Three losses were due to the hospitalization of the participant at the time of the interview, although these did not affect the results. The main reasons given for refusal to participate were: "they didn't want to be interviewed"; "the interview would take too long"; "they didn't have time to do the interview"; "they thought that interviews were a waste of time"; "they didn't believe in surveys". 
The quality control confirmed that the reproducibility of the questions investigated in the reduced questionnaire was satisfactory (Kappa values ranging between 0.6 and 0.9 ).

In the present study, most of the participants were female and the mean age was 70.4 years (standard deviation $=7.8$ and median $=69$ years), with an age range from 60 to 102 years. Many of these women claimed to be married or in a relationship and $87.0 \%$ classified their skin color as white. Concerning the socioeconomic characteristics, an expressive proportion of the participants had completed a maximum of four years of study.
However, approximately $25 \%$ of the participants had a complete higher level education. The mean percapita income was $\mathrm{R} \$ 1,348.97$ (standard deviation $=\mathrm{R} \$ 2,596.28$; median $=\mathrm{R} \$ 700.00)$. Most of the participants considered their health condition to be good or very good. More than half reported some form of dependence in relation to their activities of daily living (Table 1).

The prevalence of general violence was $12.4 \%$ (CI95\%: 10.8-14.0), while verbal violence was the most common form of violence used against the elderly participants (10.7\%; CI95\%: 9.2-12.2) (Figure 1).

Table 1. Prevalence of violence among the elderly according to sociodemographic variables and health conditions. Florianópolis, Santa Catarina, Brazil, 2009/2010.

\begin{tabular}{|c|c|c|c|c|}
\hline \multirow[t]{2}{*}{ Variables } & \multicolumn{2}{|c|}{ Sample } & \multirow{2}{*}{$\begin{array}{c}\begin{array}{c}\text { Prevalence of } \\
\text { violence }\end{array} \\
\mathrm{n}(\%)\end{array}$} & \multirow[t]{2}{*}{$\mathrm{p}$} \\
\hline & $\mathrm{N}$ & $\%$ & & \\
\hline Gender & & & & 0.000 \\
\hline Female & 1072 & 63.8 & $158(14.7)$ & \\
\hline Male & 608 & 36.2 & $51(8.4)$ & \\
\hline Age group & & & & 0.335 \\
\hline 60-69 years & 851 & 50.6 & $115(13.5)$ & \\
\hline 70-79 years & 604 & 35.9 & $71(11.7)$ & \\
\hline 80 or more & 225 & 13.4 & $23(10.2)$ & \\
\hline Marital status & & & & 0.042 \\
\hline Married/in a relationship & 984 & 58.5 & $111(11.3)$ & \\
\hline Single/divorced/separated & 230 & 13.7 & $40(17.4)$ & \\
\hline Widowed & 466 & 27.7 & $58(12.4)$ & \\
\hline Self-reported skin color & & & & 0.786 \\
\hline White & 1432 & 87.0 & $171(11.9)$ & \\
\hline Brown & 131 & 7.9 & $18(13.7)$ & \\
\hline Black & 84 & 5.1 & $9(10.8)$ & \\
\hline Education in years of study & & & & 0.005 \\
\hline 12 or more & 392 & 23.4 & $29(7.4)$ & \\
\hline 9 to 11 & 233 & 13.9 & $30(12.9)$ & \\
\hline 5 to 8 & 317 & 19.0 & $49(15.5)$ & \\
\hline 0 to 4 & 730 & 43.7 & $99(13.5)$ & \\
\hline
\end{tabular}


Continuation of Table 1

\begin{tabular}{|c|c|c|c|c|}
\hline \multirow[t]{2}{*}{ Variables } & \multicolumn{2}{|c|}{ Sample } & \multirow{2}{*}{$\begin{array}{l}\text { Prevalence of } \\
\text { violence }\end{array}$} & \multirow{2}{*}{$\begin{array}{c}\mathbf{p} \\
0.324\end{array}$} \\
\hline & & & & \\
\hline Quartile 1 (lowest) & 421 & 25.1 & $60(14.2)$ & \\
\hline Quartile 2 & 426 & 25.4 & $56(13.1)$ & \\
\hline Quartile 3 & 418 & 24.9 & $51(12.2)$ & \\
\hline Quartile 4 (highest) & 415 & 24.7 & $42(10.1)$ & \\
\hline Functional capacity & & & & 0.003 \\
\hline Independent & 457 & 27.2 & 49 (10.7) & \\
\hline Mild dependence & 709 & 42.2 & 75 (10.6) & \\
\hline Moderate/severe dependence & 514 & 30.6 & $85(16.5)$ & \\
\hline Cognitive deficit & & & & 0.195 \\
\hline No & 878 & 52.5 & $100(11.4)$ & \\
\hline Yes & 794 & 47.5 & $107(13.5$ & \\
\hline Self-perception of health & & & & 0.001 \\
\hline Good/very good & 860 & 51.3 & $88(10.2)$ & \\
\hline Regular & 645 & 38.5 & $86(13.3)$ & \\
\hline Poor/very poor & 172 & 10.3 & $34(19.8)$ & \\
\hline Caregiver & & & & 0.877 \\
\hline No & 1547 & 92.1 & $193(12.5)$ & \\
\hline Yes & 133 & 7.9 & $16(12.0)$ & \\
\hline Main caregiver & & & & 0.531 \\
\hline Spouse/partner & 35 & 26.3 & $3(8.5)$ & \\
\hline Child/grandchild & 62 & 46.6 & $9(14.5)$ & \\
\hline Formal caregiver & 23 & 17.3 & $4(17.4)$ & \\
\hline Other & 13 & 9.8 & - & \\
\hline Lives with & & & & 0.001 \\
\hline Alone & 269 & 16.0 & $36(13.4)$ & \\
\hline Professional caregiver & 12 & 0.7 & $2(16.7)$ & \\
\hline Partner/ others of their own age & 705 & 42.0 & $61(8.7)$ & \\
\hline Children or grandchildren & 692 & 41.2 & $109(15.7)$ & \\
\hline
\end{tabular}




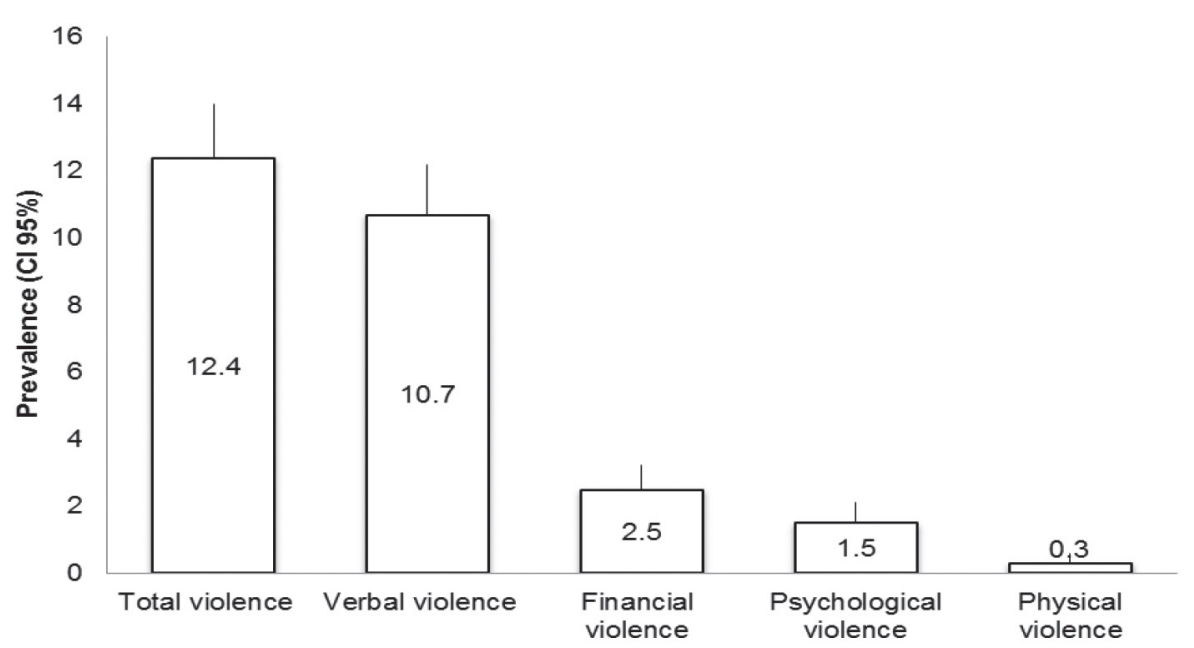

Figure 1. Prevalence of violence against the elderly. Florianópolis, Santa Catarina, Brazil, 2009/2010.

It was found that women are subjected to more violence than men. Single or divorced individuals exhibited a higher frequency of the outcome. Similarly, violence was more common among those with a lower level of education, those with moderate/severe dependence in relation to ADLs and those with a poor perception of their own health. The participants who lived alone, with a caregiver or with children/grandchildren reported higher levels of violence than those who lived with a spouse or other people of their own age (Table 1).

The crude analysis revealed that the variables correlated with the outcome were: the female gender ( $\mathrm{OR}=2.15$; CI95\%: 1.37-3.38); being married, single or divorced (OR=1.91; CI95\%: 1.28 2.86) and having completed less than 11 years of study. The chances of being subjected to violence were higher among individuals who exhibited moderate or severe dependence $(\mathrm{OR}=1.72$; $\mathrm{CI} 95 \%$ :
1.11-2.66), had a poor or very poor self-perception of their own health (OR=1.85; CI95\%: 1.15-2.99) and lived with their children or grandchildren $(\mathrm{OR}=2.52$; CI95\%: 1.58-4.03).

The female gender remained associated with the outcome in the multivariate analysis, with twice as much chance of being subjected to violence than men (CI95\%: 1.3-3.2). Single or divorced elderly individuals had a $66 \%$ greater chance of being subjected to violence (CI95\%: 1.10-2.49). Participants with lower levels of education were also more likely to be subjected to violence. Similarly, elderly individuals that exhibited moderate to severe dependence were $70 \%$ more likely to be subjected to some form of violence (CI95\%: 1.08-2.66) and those that lived with their children or grandchildren were twice as likely to be subjected to violence (CI95\%: 1.40-3.40) (Table 2). 
Table 2. Bivariate and multivariate analysis of the factors associated with reports of violence among the elderly ( $\geq 60$ years). Florianópolis, Santa Catarina, Brazil, 2009/2010.

\begin{tabular}{|c|c|c|c|c|}
\hline \multirow[t]{2}{*}{ Variables } & \multicolumn{2}{|c|}{ Bivariate analysis } & \multicolumn{2}{|c|}{ Multivariate analysis } \\
\hline & OR (CI 95\%) & $\mathrm{p}$ & OR (CI 95\%) & $\mathrm{p}$ \\
\hline Gender $(n=1678)$ & & $0.011^{*}$ & & 0.002 \\
\hline Male & 1.00 & & 1.00 & \\
\hline Female & $2.1(1.3-3.3)$ & & $2.0(1.3-3.2)$ & \\
\hline Age group (n=1678) & & $0.196^{*}$ & & 0.114 \\
\hline $60-69$ & 1.00 & & 1.00 & \\
\hline $70-79$ & $0.7(0.5-1.0)$ & & $0.7(0.5-1.0)$ & \\
\hline 80 or more & $0.7(0.4-1.3)$ & & $0.7(0.4-1.3)$ & \\
\hline Marital status ( $\mathrm{n}=1678$ ) & & $0.110^{*}$ & & 0.500 \\
\hline Married & 1.00 & & 1.00 & \\
\hline Single/divorced & $1.9(1.2-2.8)$ & & $1.6(1.1-2.4)$ & \\
\hline Widowed & $1.3(0.8-2.0)$ & & $1.0(0.6-1.7)$ & \\
\hline Education $(n=1670)$ & & $0.005^{*}$ & & 0.023 \\
\hline 12 years or more & 1.00 & & 1.00 & \\
\hline 9 to 11 years & $1.6(0.7-3.6)$ & & $1.5(0.7-3.4)$ & \\
\hline 5 to 8 years & $2.4(1.2-4.9)$ & & $2.1(1.0-4.2)$ & \\
\hline 0 to 4 years & $2.1(1.2-3.7)$ & & $1.8(1.0-3.3)$ & \\
\hline Income ( $\mathrm{n}=1678)$ & & $0.066^{*}$ & & 0.449 \\
\hline Quartile 1 & 1.00 & & 1.00 & \\
\hline Quartile 2 & $1.0(0.6-1.6)$ & & $1.0(0.6-1.6)$ & \\
\hline Quartile 3 & $0.8(0.5-1.2)$ & & $0.8(0.5-1.4)$ & \\
\hline Quartile 4 & $0.5(0.3-1.1)$ & & $0.7(0.4-1.4)$ & \\
\hline Functional capacity $(\mathrm{n}=1678)$ & & $0.011^{*}$ & & 0.018 \\
\hline Independent & 1.00 & & 1.00 & \\
\hline Mild dependence & $0.8(0.5-1.3)$ & & $0.9(0.6-1.4)$ & \\
\hline Moderate/severe dependence & $1.7(1.1-2.6)$ & & $1.7(1.0-2.6)$ & \\
\hline Cognitive deficiency $(\mathrm{n}=1670)$ & & $0.060^{*}$ & & 0.110 \\
\hline No & 1.00 & & 1.00 & \\
\hline Yes & $1.3(0.9-1.9)$ & & $1.3(1.0-1.9)$ & \\
\hline Self-perception of health $(\mathrm{n}=1675)$ & & $0.019^{*}$ & & 0.807 \\
\hline Good/ very good & 1.00 & & 1.00 & \\
\hline Regular & $1.3(0.8-1.9)$ & & $0.9(0.6-1.5)$ & \\
\hline Poor/very poor & $1.8(1.1-2.9)$ & & $1.1(0.5-2.1)$ & \\
\hline Caregiver $(\mathrm{n}=1678)$ & & 0.803 & & - \\
\hline
\end{tabular}




\begin{tabular}{lcccc}
\hline \multicolumn{1}{c}{ Variables } & \multicolumn{2}{c}{ Bivariate analysis } & \multicolumn{2}{c}{ Multivariate analysis } \\
\hline & OR $($ CI 95\%) & p & OR $($ CI 95\%) & p \\
\hline No & 1.00 & & & \\
Yes & $0.9(0.5-1.6)$ & & & \\
Main caregiver (n=120) & & 0.589 & & \\
Spouse/partner & 1.00 & & & \\
Child/grandchild & $2.8(0.6-11.9)$ & & & \\
Formal caregiver & $2.8(0.5-15.1)$ & & 1.00 & \\
Lives with (n=1691) & & $<0.001^{*}$ & & \\
Partner/ others of their own age & 1.00 & & $2.1(1.4-3.3)$ & \\
Alone & $1.6(1.0-2.8)$ & & $3.9(0.7-20.6)$ & \\
Children or grandchildren & $2.5(1.5-4.0)$ & & & \\
Professional caregiver & $3.1(0.5-16.6)$ & & & \\
\hline
\end{tabular}

$(*)$ Variables included in the multivariate analysis $(\mathrm{p}<0.20)$. (-) Variables not included in the multivariate analysis due to $\mathrm{p}>0.20$.

\section{DISCUSSION}

Population-based studies on the prevalence of violence against the elderly in Brazil are incipient and this was the first study of this type in the city of Florianópolis. The size of the sample and the methodology used ensured that the results would be representative of the elderly population living in the urban zone of Florianópolis.

Approximately $12.4 \%$ of the participants in the present study reported being subjected to some form of violence. This result is double the WHO estimate for the elderly population. ${ }^{4}$ However, other studies have shown that the prevalence of violence can range between $2.2 \%$ and $40.4 \%{ }^{16,17}$ This variation in estimates could be due to the methods applied in studies and interviews, especially considering that the interview may be conducted in the presence of caregivers and/or family members. The results could also be affected by the understanding of the concept of violence of the elderly individual.

Psychological violence was the most common form of violence in the present study. Previous studies ${ }^{17,18}$ have also confirmed this to be the most common form, while suggesting that this type of violence increases the possibility of other types of violence occurring, since it places the elderly individual in a situation of humiliation and fear, which allows the aggressor to continue or commit other types of abuse.

Financial violence was the second most common form of violence in the present study. Adams ${ }^{19}$ reported that this was the most common form of abuse among elderly individuals in Australia, as it was so difficult to detect. The person responsible for the violence is usually somebody close to the elderly individual, which reduces the chances of the victim reporting the abuse.

In the present study, women were subjected to more violence than men, as reported in several previous studies of violence. ${ }^{20,21}$ This association was maintained in the adjusted analysis, showing that women were twice as likely to be subjected to violence as men. A recent systematic review ${ }^{21}$ indicated that women are subjected to violence at all ages and are more susceptible to violence, particularly when they are elderly. 
The present study contained a high prevalence of elderly individuals with a higher level education (23.4\%), when compared with other regions in Brazil (12\%). It was notable that elderly individuals with higher education levels were subjected to less violence than those with lower education levels.

Single or widowed elderly individuals with a low level of education were more likely to be subjected to violence. The absence of a companion is potentially associated with neglect among the elderly, ${ }^{22}$ while education is associated with an increase in the chances of the individual being subjected to violence. ${ }^{23}$

Moderate and severe dependence were strongly correlated with the outcome, possibly due to the fact that speech and/or locomotion dependence make an individual more susceptible to violence and decrease the likelihood of the aggressor being reported or arrested. Significant causes of intergenerational conflict include: the elderly individual's need for care as he or she gets older; the onset of an illness; forgetfulness; mental confusion; sleep disorders; incontinence; locomotion difficulties; and impaired functional capacity. All of these issues can create problems and increase the demand for care from children and grandchildren. ${ }^{24}$

A study conducted in São Paulo demonstrated that moderate or severe dependence is a potential factor associated with the negligence of this population. ${ }^{22} \mathrm{~A}$ greater dependence in the performance of activities of daily living leads to a greater risk of the elderly individual in question being subjected to some form of violence.

In the present study, living with children or grandchildren significantly increased the chances of being subjected to violence. Amstadter ${ }^{25}$ reported that approximately $10 \%$ of all elderly individuals are subjected to some form of mistreatment, and the aggressor generally lives with the victim. This finding has been corroborated by other authors who have shown that elderly individuals living with their children or close relatives are more commonly mistreated by these family members, when compared to others. ${ }^{26,27}$ Other international results corroborate these findings, indicating that the perpetrators of violence against the elderly were: children (50\%); other relatives $(24 \%)$; spouses or partners $(20 \%)$; friends $(4 \%)$ and caregivers $(2 \%){ }^{16}$

The gradual increase in reports and studies of these cases of violence can be partly explained by a transformation in the elderly assistance policy, the statute of which indicates that it is a duty of all Brazilians to prevent the rights of the elderly from being threatened or violated. ${ }^{28}$ The domestic environment is a suitable place to investigate violence against the elderly. The frequency of this violence and the factors associated with this phenomenon are essential in studies of this nature. $^{20}$

Violence causes irreversible sequelae for the victims. Studies have shown that the consequences of violence include: poor health conditions; stomach problems; headaches; obesity; allergies; anxiety; sleep disorders and stress. ${ }^{29}$

Therefore, the complexity of violence, as well as its causes, perpetrators and forms of expression, make it a challenging subject to discuss and tackle. The first step in preventing violence is to identify it through public health policies and programs. ${ }^{30}$

The strong points of the present study include the population coverage and the representativeness of the sample. The limitations include the cross-sectional design, which did not favor the establishment of causality - such as knowing whether the elderly individual classified their health as poor/very poor or if an illness was present prior to the mistreatment. Other limitations include the performance of the interview in the home of the participant and the fact that the instrument used to investigate violence against the elderly has not been validated, although it has been used in previous studies. ${ }^{13}$

In closing, the present study provided a panorama of the situation of violence to which the elderly residents of Florianópolis are subjected. 


\section{CONCLUSION}

The results of the present study indicate that violence against the elderly is higher than the levels expected by the WHO or other studies. These differences could be due to the distinct methods adopted in research projects, although it is probable that the estimates are even higher, since this is a delicate issue. Elderly individuals are often afraid to admit that they are being subjected to violence. In general, the perpetrators of the violence are family members, which leads to the elderly individual hiding the real facts of the situation.

Elderly individuals who live with their children and grandchildren are subjected to more violence than those who live with others. Violence is more common against single/divorced women with a low level of education and some form of functional dependence. These results show that family members who are caregivers must receive support if these rates are to fall. The results also demonstrate the significant social inequalities involved in violence against elderly individuals in Florianópolis.

Public policies and planning strategies are required to provide a structure so that elderly individuals, as well as their families and/or caregivers, are supported and violence levels are reduced. Health professionals and police officers must protect and advise elderly individuals who are subjected to violence, while also seeking to identify, monitor and prevent the occurrence of violence.

\section{REFERENCES}

1. Instituto de Pesquisa Econômica Aplicada. PNAD 2009 - Primeiras Análises: Tendências Demográficas. Brasília, DF: IPEA; 2010.

2. Brasil. Portaria $n^{\circ} 2.528$. Aprova a Política Nacional de Saúde da Pessoa Idosa. Diário Oficial da União; 19 out 2006

3. Brasil. Lei no 10.741. Dispõe sobre o Estatuto do Idoso e dá outras providências. Diário Oficial da União; 01 out 2003.

4. Organização Mundial da Saúde. Relatório mundial sobre violência e saúde. Genebra: OMS; 2002.

5. Acierno R, Hernandez MA, Amstadter AB, Resnick HS, Steve K, Muzzy W, et al. Prevalence and correlates of emotional, physical, sexual, and financial abuse and potential neglect in the United States: the National Elder Mistreatment Study. Am J Public Health 2010;100(2):292-7.

6. Cadmus EO, Owoaje ET. Prevalence and correlates of elder abuse among older women in rural and urban communities in South Western Nigeria. Health Care Women Int 2012;33(10):973-84

7. Apratto JPC. A violência doméstica contra idosos nas áreas de abrangência do Programa Saúde da Família de Niterói (RJ, Brasil). Ciênc Saúde Coletiva 2010;15(6):2983-95.

8. Naughton C, Drennan J, Lyons I, Lafferty A. The relationship between older people's awareness of the term elder abuse and actual experiences of elder abuse. Int Psychogeriatr 2013;25(8):1257-66.
9. Faustino AM, Gandolfi L, Moura LBA. Capacidade funcional e situações de violência em idosos. Acta Paul Enferm 2014; 27(5):392-8.

10. Abath MB, Leal MCC, De Melo Filho DA. Fatores associados à violência doméstica contra a pessoa idosa. Rev Bras Geriatr Gerontol 2012;15(2):305-14.

11. Oliveira RCS. A pesquisa sobre o idoso no Brasil: diferentes abordagens sobre educação nas teses e dissertações (de 2000 a 2009). Acta Sci Educ 2013;35(1):79-87.

12. Ribeiro AP, Barter EACP. Atendimento de reabilitação à pessoa idosa vítima de acidentes e violência em distintas regiões do Brasil. Ciênc Saúde Coletiva 2010;15(6):2729-40.

13. Lebrão LM.Estudo Longitudinal sobre as condições de vida e de saúde dos idosos do Município de São Paulo, 2006 [Internet]. Brasília, DF: OPAS; 2006. [acesso em 20 abr 2016 ]. Disponível em: http://www. fsp.usp.br/sabe/Extras/Livro_SABE.pdf

14. Rosa TEC, D’Aquino MHB, Latorreb MRDO, Ramos LR. Fatores determinantes da capacidade funcional entre idosos. Rev Saúde Pública 2003;3(1)7:40-8.

15. Brucki SM, NitriniR, Caramelli P, Bertolucci PHF, Okamoto IH . Sugestões para o uso do Mini-Exame do Estado Mental no Brasil. Arq. Neuropsiquiatr. 2003;61(3B):777-81.

16. Naughton C, Drennan J, Lyons I, Lafferty A, Treacy M, Phelan A, et al. Elder abuse and neglect in Ireland: results from a national prevalence survey. Age Ageing 2012;41(1):98-103. 
17. DeLiema M, Gassoumis ZD, Homeier DC, Wilber $\mathrm{KH}$. Determining prevalence and correlates of elder abuse using promotores: low-income immigrant Latinos report high rates of abuse and neglect. J Am Geriatr Soc 2012;60(7):1333-9.

18. Wu L, Chen H, Hu Y, Xiang H, Yu X, Zhang T, et al. Prevalence and associated factors of elder mistreatment in a rural community in people's Republic of China: a cross-sectional study. PLoS One 2012;7(3):1-8.

19. Adams VM, Bagshaw D, Wendt S, Zannettino L. Financial abuse of older people by a family member: a difficult terrain for service providers in Australia. J Elder Abuse Negl 2014 26(3):270-90.

20. Duque AM, Leal MCC, Marques APO, Eskinazi FMV, Duque AM. Violência contra idosos no ambiente doméstico: prevalência e fatores associados (Recife/ PE). Ciênc Saúde Coletiva 2012;17(8):2199-208.

21. Da Silva ACLG, Coelho EBS, Moretti-Pires RO. O que se sabe sobre o homem autor de violência contra a parceira íntima: uma revisão sistemática. Rev Panam Salud Publica 2014; 35(4):278-83.

22. De Queiroz ZPV, Lemos NFD, Ramos LR. Fatores potencialmente associados à negligência doméstica entre idosos atendidos em programa de assistência domiciliar. Ciênc Saúde Coletiva 2010;15(6):2815-24.

23. Pinto FNFR, Barham EJ, De Albuquerque PP. Idosos vítimas de violência: fatores sóciodemográficos e subsídios para futuras intervenções. Estudos e Pesquisas em Psicologia. 2013;13(3):1159-81.
24. Wanderbroocke ACNS. A violência familiar na perspectiva de idosos e profissionais no contexto da atenção primária à Saúde [tese]. Florianópolis (SC): Universidade Federal de Santa Catarina; 2011.

25. Amstadter AB, Cisler JM, McCauley JL, Hernandez MA, Muzzy W, Acierno R. Do incident and perpetrator characteristics of elder mistreatment differ by gender of the victim? Results from the National Elder Mistreatment Study. J Elder Abuse Negl 2011;23(1):43-57.

26. Clancy M, McDaid B, O'Neill D, O'Brien JG. National profiling of elder abuse referrals. Age Ageing 2011;40(3):346-52.

27. Heydrich LV, Schiamberg LB, Chee G. Socialrelational risk factors for predicting elder physical abuse: an ecological bi-focal model. Int J Aging Hum Dev 2012;75(1):71-94.

28. Oliveira MLC, Gomes ACG, Amaral CPM, Dos Santos LB. Características dos idosos vítimas de violência doméstica no Distrito Federal. Rev Bras Geriatr Gerontol 2012;15(3):555-66.

29. Olofsson N, Lindqvist K, Danielsson I. Fear of crime and psychological and physical abuse associated with ill health in a Swedish population aged 65-84 years. Public Health 2012;126(4):358-64.

30. Oveisi S, Karimi R, Mahram M. Note from Iran: Selfreported elder abuse in Qazvin, 2012. J Elder Abuse Negl 2014;26(3):337-40. 